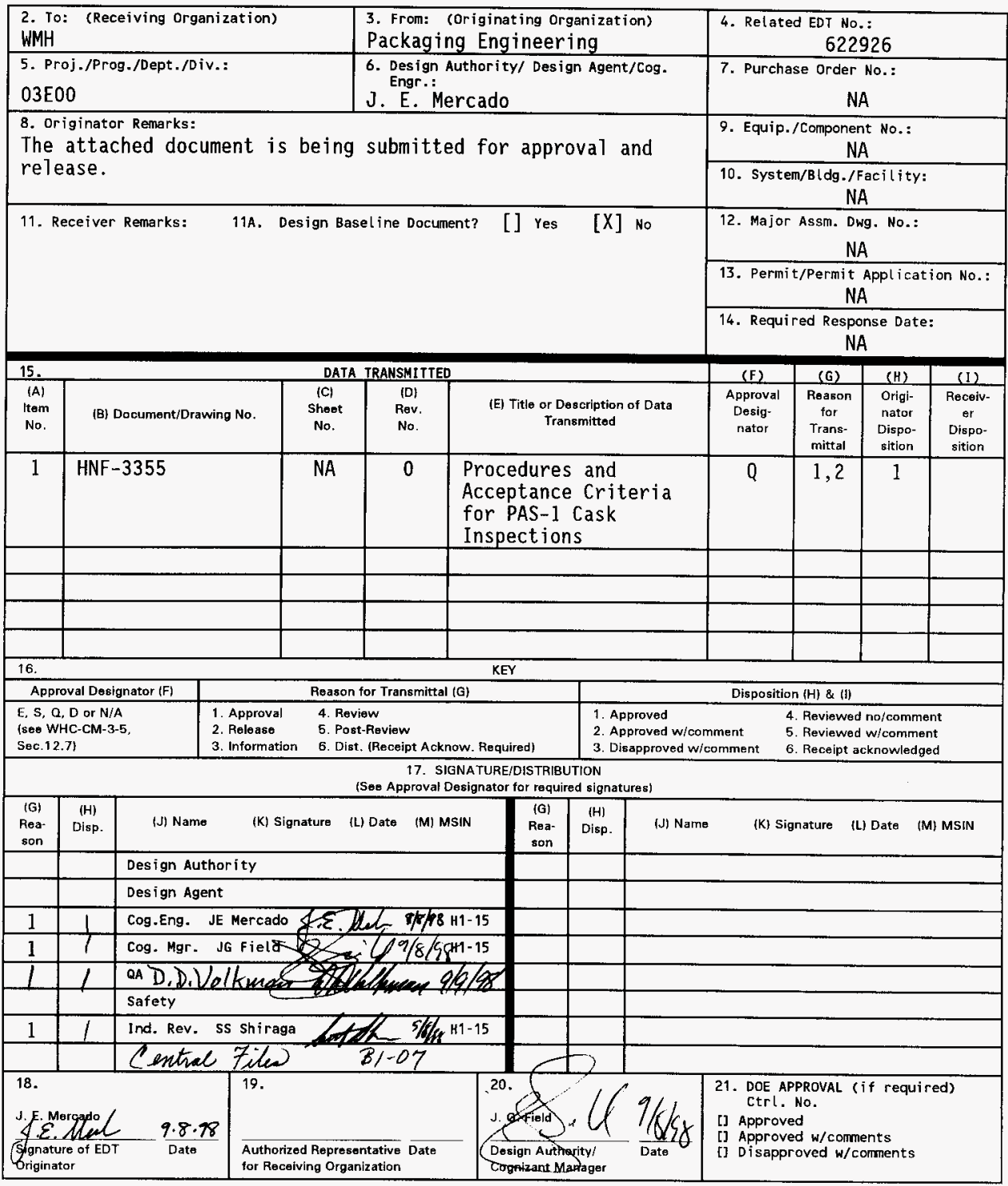




\section{Procedures and Acceptance Criteria for PAS-1 Cask Inspections}

\section{J. E. Mercado}

Waste Management Federal Services, Inc., Northwest Operations Richland, Washington 99352

for Fluor Daniel Hanford, Inc.

U.S. Department of Energy Contract DE-AC06-96RL13200

EDT/ECN: EDT 622953

Org Code: 03E00

B\&R Code: EW3120074
UC: 513

Charge Code: N4K4G Task Order: GS080003

Project: 772031 Crosswalk: 40-017-045

Key Words: Certificate of Compliance, dimensional inspection, visua? weld inspection

Abstract: The procedures and acceptance criteria that comprise this document were prepared to support a one-time test to certify two PAS-1 casks in accordance with U.S. Department of Energy Certificate of Compliance USA/9184/B(U), which was issued in 1998. The specific inspections addressed in this document are the visual weld inspection and a dimensional inspection of the primary containment vessel.

IRADEMARK DISCLAIMER. Reference herein to any specific commercial product, process, or service by trade name, trademark, manufacturer, or otherwise, does not necessarily constitute or imply its endorsement, recommendation, or favoring by the United States Government or any agency thereof or its contractors or subcontractors.

Printed in the United States of America. To obtain copies of this document, contact: WhC/BCS Document Control Services, P.O. Box 1970, Mailstop H6-08, Richland WA 99352, Phone (509) 372-2420; Fax (509) 376-4989.
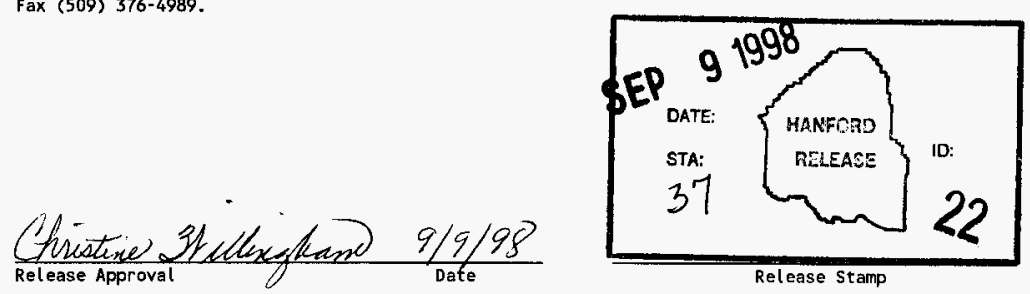

Approved for Public Release 


\section{PROCEDURES AND ACCEPTANCE CRITERIA FOR PAS-1 CASK INSPECTIONS}

The procedures and acceptance criteria that comprise this document were prepared to support a one time test to certify two PA.S-1 casks in accordance with DOE Certificate of Compliance USA $9184 / B(U)$, which was issued in 1998.

The specific inspections addressed in this document are the visual weld inspection and a dimensional inspection of the primary containment vessel. 
HNF-3355 Rev. 0

\section{DIMENSIONAL INSPECTION PROCEDURE}

\subsection{SCOPE}

This procedure addresses the dimensional inspection of the PAS-1 primary containment vessel (PCV).

\subsection{REQUIREMENTS}

Inspections shall be performed with rulers, squares, and scales with graduations of 0.01 in. Dimensional measurements shall be made to detect deformation at the center of PCV end plates and at the radial sides near the end plate weld. Any deformation greater than $1 / 32$ in. that results from the pressure test is cause to reject both pressure vessels from shipping Payload B.

Acceptable tolerances are $\pm 1 / 16$ in. unless otherwise specified in this procedure.

Locations of measurements shall be marked with tape or suitable ink and indexed to a fixed point on the vessel for reproducibility.

\subsection{INSTRUCTIONS}

1. This procedure shall be performed before and after the pressure test of the PCV.

2. To the maximum extent practicable, record measurements photographically.

3. Measure ID and OD of PCV base at top, center, and bottom ranges of the vessel (3 locations), each set of measurements to be spaced $120^{\circ}$ (nominal) apart. Mark each measurement location with suitable marking ink. Record measurements in Table 1.

4. Measure ID and OD of PCV lid at top, center, and bottom heights ( 3 locations), each set of measurements to be spaced $120^{\circ}$ (nominal) apart. Mark each measurement location with suitable marking ink. Record measurements in Table 1.

5. Use a square positioned on the bottom plate and measure the distance between the cylindrical wall of the PCV base and the square at three locations (bottom, at half height, and at landing), to obtain 3 sets of measurements spaced $120^{\circ}$ (nominal) apart. Mark each measurement location with a suitable marking ink or tape. Record measurements in Table 1.

6. Use a square positioned on the bottom plate and measure the distance between the cylindrical wall of the PCV lid and the square at three locations (top at half height, and at edge), to obtain 3 sets of measurements spaced $120^{\circ}$ (nominal) apart. Mark each measurement location with a suitable marking ink or tape. Record measurements in Table 1.

7. Use reference straight edge to check for bulging on the exterior surface of the 
bottom plate ( 3 orientations, spaced $120^{\circ}$ (nominal) apart). Mark each inspection location with suitable marking ink or tape. Record results in Table 1.

8. Use reference straight edge to check for bulging on the exterior surface of the top plate ( 3 orientations, spaced $120^{\circ}$ (nominal) apart). Mark each inspection location with suitable marking ink or tape. Record results in Table 1.

9. Perform pressure test.

10. Perform steps 3 through 8 , using the reference marks from the first series of measurements to duplicate the procedure. Record results in Table 2.

\subsection{REFERENCES}

DOE, 1998, U.S. Department of Energy Certificate of Compliance for Radioactive Materials Packages, Number 9184, Rev. 0, U.S. Department of Energy, Washington, D.C.

Pacific Nuclear, 1993, Fabrication Pacific Nuclear PAS-1 Primary Container, drawing GM-20-01D,

Rev, B, Pacific Nuclear, Federal Way, Washington. 
HNF-3355 Rev. 0

Table 1.

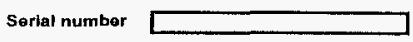

Initial Moasurements and Inspections

record all dimensions in inches

\begin{tabular}{|c|c|c|c|}
\hline Base & TD $O D$ & ID & TID OD \\
\hline Vertical location & 0 degrees & 120 degrees & 240 degrees \\
\hline \multicolumn{4}{|l|}{ top } \\
\hline \multicolumn{4}{|l|}{ center } \\
\hline \multicolumn{4}{|l|}{ bottom } \\
\hline Eid & 00 & $\mathrm{OD}$ & OD \\
\hline Vertical location & 0 degrees & 120 degrees & 240 degrees \\
\hline \multicolumn{4}{|l|}{ top } \\
\hline \multicolumn{4}{|l|}{ center } \\
\hline Bottom & & & \\
\hline
\end{tabular}

\begin{tabular}{|l|c|c|c|}
\hline Base & & \multicolumn{3}{|c|}{ distance to square } \\
\hline Vertical localion & 0 degrees & 120 degrees & 240 degrees \\
\hline boltom & & & \\
\hline half height & & & \\
\hline Landing & & & \\
\hline
\end{tabular}

\begin{tabular}{|l|r|r|r|}
\hline Lid & \multicolumn{3}{|c|}{ distance to square } \\
\hline Vertical location & 0 degrees & 120 degrees & 240 degrees \\
\hline top & & & \\
\hline half height & & & \\
\hline edge & & & \\
\hline
\end{tabular}

\begin{tabular}{|l|r|r|r|}
\hline Baso & \multicolumn{3}{|c|}{ Botlom plate inspection } \\
\hline & O degrees & 120 degrees & 240 degrees \\
\hline & & & \\
\hline & & & \\
\hline & & & \\
\hline
\end{tabular}

\begin{tabular}{|l|c|c|c|}
\hline Lid & \multicolumn{3}{|c|}{ Top plate inspection } \\
\hline & 0 degrees & 120 degrees & 240 degrees \\
\hline & & & \\
\hline & & & \\
\hline & & & \\
\hline
\end{tabular}

Comments:

Inspector:

date: 
HNF-3355 Rev. 0

Table 2.

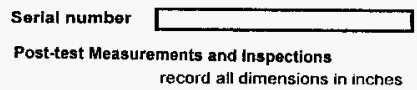

\begin{tabular}{|c|c|c|c|}
\hline Elaso & OD & 00 & OD \\
\hline Vertical location & 0 degrees & 120 degrees & 240 degrees \\
\hline \multicolumn{4}{|l|}{ top } \\
\hline center & & & \\
\hline bottom & & & \\
\hline
\end{tabular}

\begin{tabular}{|c|c|c|c|}
\hline Lid & ID OD & ID OD & OD \\
\hline Vertical tocation & 0 degrees & 120 degrees & 240 degrees \\
\hline top & & & \\
\hline Center & & & \\
\hline bottom & & & \\
\hline
\end{tabular}

\begin{tabular}{|l|c|c|c|}
\hline Baso & \multicolumn{3}{|c|}{ distance to square } \\
\hline Vertical location & 0 degrees & 120 degrees & 240 degrees \\
\hline boltom & & & \\
\hline half height & & & \\
\hline Janding & & & \\
\hline
\end{tabular}

\begin{tabular}{|l|c|c|c|}
\hline Lid & & distance to square \\
\hline Vertical location & 0 degrees & 120 degrees & 240 degrees \\
\hline top & & & \\
\hline half height & & & \\
\hline edge & & & \\
\hline
\end{tabular}

\begin{tabular}{|l|c|c|c|}
\hline Baso & \multicolumn{3}{|c|}{ Bottom plate inspection } \\
\hline & 0 degrees & 120 degrees & 240 degrees \\
\hline & & & \\
\hline & & & \\
\hline & & & \\
\hline
\end{tabular}

\begin{tabular}{|l|c|c|c|}
\hline & \multicolumn{3}{|c|}{ Top plate inspection } \\
\hline & 0 degrees & 120 degrees & 240 degrees \\
\hline & & & \\
\hline & & & \\
\hline & & & \\
\hline
\end{tabular}

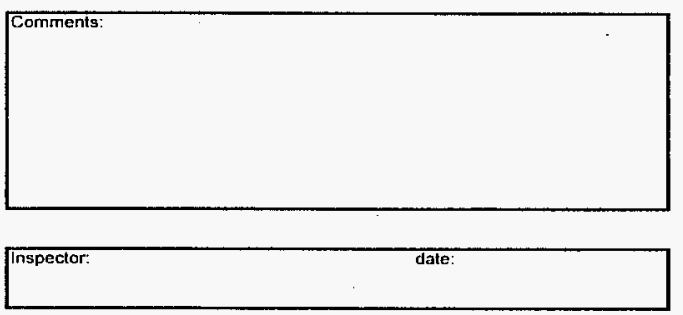


HNF-3355 Rev. 0

\section{VISUAL WELD INSPECTION PROCEDURE}

\subsection{SCOPE}

This procedure addresses the visual inspection of the welds of the PAS- 1 primary containment vessel (PCV).

\subsection{REQUIREMENTS}

The PAS-1 PCV welds shall be inspected in accordance with the requirements of HNF-PRO-1607, Visual Weld Inspection, as applicable to completed welds.

No grinding shall be performed on the PAS-1 PCV.

\subsection{INSTRUCTIONS}

11. Direct inspection shall be used to perform this procedure whenever possible.

12. This procedure shall be performed before and after the pressure test of the PCV.

13. Surfaces may be cleaned as necessary as directed by the cognizant engineer.

14. Welds to be examined:

\begin{tabular}{|l|l|l|}
\hline$\#$ & Location & Size/Type \\
\hline 1 & Base Interior & $1 / 4-$ fillet \\
\hline 2 & Base Exterior & $1 / 4-$ groove \\
\hline 3 & Lid Interior & $1 / 4-$ fillet \\
\hline 4 & Lid Exterior & $1 / 4-$ groove \\
\hline
\end{tabular}

\subsection{ACCEPTANCE CRITERIA}

a. Weld cracks - there shall be no evidence of cracks.

b. Fillet weld size - fillet welds are permitted to be smaller than the size specified by $1 / 16$ in. for $10 \%$ of the length of the weld. Oversized fillet welds are acceptable.

c. Fusion - thorough fusion shall exist between adjacent layers of weld metal and between weld metal and base metal.

d. Weld overlap - the weld shall have no overlap.

e. Craters - all craters shall be filled to the full cross-section of the weld.

f. Undercut - undercut shall not exceed $1 / 32$ in. 
g. Surface porosity - the sum of diameters of random porosity shall not exceed $1 / 4$ in. in any linear inch of weld or $3 / 8 \mathrm{in}$. in any $4 \mathrm{in.} \mathrm{of} \mathrm{weld.}$

h. Weld length and location - the length and location of welds shall be as specified in the referenced drawing.

i. Oxidation - all welds shall be free of oxidation to improper shielding and overheating which produce black or gray spalling or loose particles. Iridescent temper films and the dark metallic vapor deposits which may occur adjacent to the weld are acceptable. These films and deposits shall be removed with appropriate cleaning methods.

j. Corrosion - all welds shall be free of evidence of general or localized corrosion. General corrosion shall be removed. All welds shall be examined to $10 \mathrm{X}$ magnification or greater for evidence of intergranular corrosion. Localized or intergranular corrosion shall be cause for rejection of that pressure vessel for shipping Payload B.

15. Inspect specified welds in accordance with the above criteria.

6. Record results in Appendix A.

\subsection{REFERENCES}

HNF-PRO-1607, Visual Weld Inspection, Fluor Daniel Hanford, Inc., Richland, Washington.

Pacific Nuclear, 1993, Fabrication Pacific Nuclear PAS-1 Primary Container, drawing GM-20-01D, Rev. B, Pacific Nuclear, Federal Way, Washington. 
HNF-3355 Rev. 0

APPENDIX A: VISUAL WELD INSPECTION REPORT.

PAS-1 Cask Serial Number 2162-026

\begin{tabular}{|lll|}
\hline Company: & \\
\hline Inspector: & \\
\hline Weld \# & accept & reject \\
\hline Weld \# & accept & reject \\
\hline Weld \# & accept & reject \\
\hline Weld \# & accept & reject \\
\hline
\end{tabular}

PAS-1 Cask Serial Number 2162-027

\begin{tabular}{|c|c|c|}
\hline Compan & & \\
\hline Inspecto & & \\
\hline Weld \# & accept & reject \\
\hline Weld \# & accept & reject \\
\hline Weld \# & accept & reject \\
\hline Weld \# & accept & reject \\
\hline
\end{tabular}

QA signature:

Date: 